\title{
Analysis of Water Quality Using Physico-Chemical Parameters of Khudia Dam in Mungeli District, Chhattisgarh
}

\author{
Dr. Manish Upadhyay ${ }^{1}$, Vijay Laxmi Gupta ${ }^{2}$ \\ ${ }^{1}$ Associate Professor, HOD, Department of Chemistry, Dr. C V Raman University, Kota, Bilaspur- (C.G) \\ ${ }^{2}$ Research Scholar, Dr. C V Raman University, Kota, Bilaspur- (C.G)
}

\begin{abstract}
This Paper Present to study of the Physico-chemical Parameters of Khudia Dam in Mungeli District, Chhattisgarh. Monthly Changes In Physical and Chemical Parameters Such as Water Temperature, Transparency, Turbidity, Total Dissolved Solids, pH, Dissolved Oxygen, Free Carbon dioxide, and Total Hardness, Chlorides, Alkalinity, Phosphate and Nitrates. Were analyzed for a periods of one year from $1^{\text {st }}$ January 2012 to 31st December 2012. All Parameters were within the Permissible limits. The results indicate that the Dam is Non-polluted and can be used for Domestic, Irrigation and Pisciculture.
\end{abstract}

Keywords:- Aquatic ,Perennial, Physico-Chemical Parameters, Monthly variation.

\section{INTRODUCTION}

Water is one of the most Important Compound to the Ecosystem. Better Quality of water Described by its Physical, Chemical and Biological Characteristics. But some Correlation was Possible among these Parameters and the Significant One would be Useful to Indicate Quality of water. Due to Increased Human Population, Industrialization, Use of Fertilizers in Agriculture and Man-made activity. The Natural Aquatic Resources are causing Heavy and varied Pollution in aquatic Environment Leading to water Quality and Depletion of aquatic Biota. It is therefore Necessary that the Quality of Drinking water should be checked at regular time interval because due to use of Contaminated Drinking water, Human Population Suffers From a variety of Water Borne Diseases. It is difficult to understand The Biological Phenomena fully because the Chemistry of water reveals much about the Metabolism of The Ecosystem and explain the General Hydro Biological Relationship. The Physico-chemical Parameters of water and the dependence of all life process of these factors make it desirable to take as an environ In Present Study involves the Analysis of Water Quality in Terms of Physico-chemical Parameters of Khudia dam, Mungeli District, Chhattisgarh. The dam water is basically used for Domestic, Agriculture Purpose and Fisheries Activity. In India Still now several Researchers have done Study on Physicochemical and Biological characteristic of Standing and Running Water Resources [1-3]

\section{MATERIALS AND METHODS}

The Water Samples from Khudia dam were collected from four Different Stations in the Morning Hours between 9 to $11 \mathrm{am}$, in Polythene Bottle Regularly for Every Month. The Water samples were immediately brought in to Laboratory for the Estimation of various Physico-chemical Parameters like Water Temperature Transparency and $\mathrm{pH}$ were recorded at the time of Sample Collection, by using Thermometer and Pocket Digital pH Meter. Transparency was measured with the help of secchi disc while other Parameters Such as DO, TDS, Free CO2, Hardness, Chlorides, Alkalinity, Phosphate and Nitrate were Estimated in the Laboratory By using Standard Methods as Prescribed By APHA, AWWA, [4], Trivedy and Goel [2],Kodarkar [3].

\section{RESULTS AND DISCUSSION:-}

The Monthly Variation in Physico-chemical Parameters is Presented in Table.

Table 1: Physical parameters of Khudia dam, Mungeli Dist, Chhattisgarh

\begin{tabular}{|l|l|l|l|l|l|}
\hline Month & $\begin{array}{l}\text { Temperature } \\
\text { oC }\end{array}$ & $\begin{array}{l}\text { Transparency } \\
\text { cm }\end{array}$ & $\begin{array}{l}\text { Turbidity } \\
\text { NTU }\end{array}$ & $\begin{array}{l}\text { TDS } \\
\text { gm/lit }\end{array}$ & pH \\
\hline Jan & 23 & 14 & 11 & $\mathbf{0 . 3 9}$ & $\mathbf{8 . 0}$ \\
\hline Feb & $\mathbf{2 4}$ & $\mathbf{1 2}$ & $\mathbf{1 0}$ & $\mathbf{0 . 2 7}$ & $\mathbf{8 . 7}$ \\
\hline Mar & $\mathbf{2 6}$ & $\mathbf{9 . 0}$ & $\mathbf{1 2}$ & $\mathbf{0 . 3}$ & $\mathbf{8 . 8}$ \\
\hline
\end{tabular}




\begin{tabular}{|l|l|l|l|l|l|}
\hline Apr & 23 & 7.5 & 9 & 0.1 & 8.0 \\
\hline May & 25 & 6.0 & 7 & 0.6 & 8.0 \\
\hline Jun & 23.5 & 10 & 13 & 2.0 & 8.4 \\
\hline Jul & 24 & 55 & 1.0 & 1.13 & 8.1 \\
\hline Aug & 24.5 & 61 & 3 & 0.2 & 8.3 \\
\hline Sep & 25.5 & 52 & 4 & 0.4 & 7.7 \\
\hline Oct & 25.5 & 92.0 & 0.4 & 0.4 & 7.5 \\
\hline Nov & 25 & $\mathbf{8 0}$ & $\mathbf{1 . 8}$ & $\mathbf{1 . 8}$ & $\mathbf{7 . 4}$ \\
\hline Dec & 22.5 & 65 & 2 & 0.4 & 8.2 \\
\hline
\end{tabular}

\section{Water Temperature -}

In The Present Study of the Water Temperature Ranges From $22.5^{\circ} \mathrm{c}$ to $26^{\circ} \mathrm{C}$. The Maximum $\left(26^{\circ} \mathrm{C}\right)$ Temperature wasrecorded in the Month of March (summer) and minimum $\left(22.5^{\circ} \mathrm{C}\right)$ in the month of December (winter). It showed that Higher Temperature in summer and relatively lowers in winter. Similar study, Jayabhaye et al;[5], Salve and Hiware[6], Observed that during Summer, Water Temperature was high due to Low Water Level, High Temperature and clear atmosphere. Water Temperature Plays an Important Factor which Influences the chemical, Biochemical and Biological characteristics of water body.

\section{Water transparency-}

Transparency of Water Fluctuates from $6.0 \mathrm{~cm}$ to $92.0 \mathrm{~cm}$. The Maximum $(92.0 \mathrm{~cm})$ was recorded in the month of October (winter) and minimum $(6.0 \mathrm{~cm})$ in the month of May during summer. Khan and Chowdhury [7] reported that higher transparency occurred, during winter and summer due to absence of rain, runoff and flood water as well as gradual settling of suspended particles. Kadam, et al; [8], also reported similar observation from Masoli reservoir.

Turbidity- .

The turbidity of water fluctuates from $0.4 \mathrm{NTU}$ to $12.41 \mathrm{NTU}$. The maximum values (12.14 NTU) was recorded in the month of February (summer) It might be due to human activities, decrease in the water level and presence of suspended particulate matter, and minimum value (0.4NTU) in the month of October.

\section{Total dissolved solids-}

The total dissolved solids fluctuate from $0.1 \mathrm{~g} / \mathrm{l}$ to $2.2 \mathrm{~g} / \mathrm{l}$. the maximum value $(2.2 \mathrm{~g} / \mathrm{l})$ was recorded in the month of June. It is due to heavy rainfall and minimum value $(0.1 \mathrm{~g} / \mathrm{l})$ in the month of April.

pH-

The $\mathrm{pH}$ was alkaline values ranges from 7.3 to 8.8 . The maximum $\mathrm{pH}$ value (8.8) was recorded in the month of May (summer) and minimum (7.3) in the month of September. The factors like air temperature bring about changes the $\mathrm{pH}$ of water. Most of bio-chemical and chemical reactions are influenced by the $\mathrm{pH}$. The reduced rate of photosynthetic activities reduces the assimilation of carbon dioxide and bicarbonates which are ultimately responsible for increase in $\mathrm{pH}$, the low oxygen values coincided with high temperature during the summer month [9].

Chemical parameters of Khudia dam, Mungeli Dist, Chhattisgarh

\begin{tabular}{|l|l|l|l|l|l|l|l|}
\hline Months & $\begin{array}{l}\text { Dissolved } \\
\text { oxygen }\end{array}$ & $\begin{array}{l}\text { Free } \\
\text { Co2 }\end{array}$ & Hardness & Chloride & Alkalinity & Phosphate & Nitrate \\
\hline Jan & 8.0 & 4.4 & 80.0 & 42.0 & 120.0 & 1.91 & 8.0 \\
\hline Feb & 9.05 & --- & 80.00 & 30.0 & 123.0 & 3.3 & 10.84 \\
\hline Mar & 12.5 & 4.0 & 102 & 44.0 & 180 & 3.39 & 12.0 \\
\hline Apr & 12.0 & 5.4 & 170 & 45.0 & 150 & 4.14 & 25.0 \\
\hline May & 12.6 & 3.4 & 142 & 57 & 200 & 4.8 & 33.0 \\
\hline Jun & 12.0 & 8.6 & 160 & 41.0 & 170 & 11.12 & 13.05 \\
\hline Jul & 10.04 & 9.8 & 75 & 44.0 & 155 & 10.68 & 35.8 \\
\hline Aug & 9.79 & 6.0 & 90 & 47.57 & 190 & 12.38 & 12.0 \\
\hline Sep & 9.05 & 20 & 104 & 38.34 & 190 & 4.58 & 4.88 \\
\hline Oct & 8.82 & 13.2 & 70 & 42.6 & 170 & 0.1 & 4.43 \\
\hline Nov & 6.40 & 15.0 & 110 & 44.55 & 150 & 0.19 & 4.40 \\
\hline Dec & 9.21 & 22.6 & 88 & 48.61 & 140 & 5.5 & 5.25 \\
\hline
\end{tabular}




\section{Dissolved Oxygen-}

The values of DO fluctuates from $6.40 \mathrm{mg} / \mathrm{l}$ to $12.6 \mathrm{mg} / \mathrm{l}$. The maximum values $(12.6 \mathrm{mg} / \mathrm{l})$ was recorded in the month of May (summer) and minimum values $(6.40 \mathrm{mg} / \mathrm{l})$ in the month of November (winter). The high DO in summer is due to increase in temperature and duration of bright sunlight has influence on the \% of soluble gases $\left(\mathrm{O}^{2} \& \mathrm{Co}^{2}\right)$. The long days and intense sunlight during summer seem to accelerate photosynthesis by phytoplankton, utilizing $\mathrm{Co}_{2}$ and giving off oxygen. This possibly accounts for the greater qualities of $\mathrm{O}_{2}$ recorded during summer. The quality is slightly lesser during winter, reported by [10].

\section{Free Carbon dioxide-}

The value of free $\mathrm{Co} 2$ ranges from $0.0 \mathrm{mg} / \mathrm{l}$ to $28.6 \mathrm{mg} / \mathrm{l}$. The maximum value $(28.6 \mathrm{mg} / \mathrm{l})$ was recorded in the month of December (winter) and minimum value $(0.0 \mathrm{mg} / \mathrm{l})$ in the month of March. This may be depends upon alkalinity and hardness of water body. The value of $\mathrm{CO}_{2}$ was high in December. This could be related to the high rate of decomposition in the warmer months.

\section{Hardness -}

The value of hardness fluctuates from $70 \mathrm{mg} / \mathrm{l}$ to $179 \mathrm{mg} / \mathrm{l}$. The maximum value $(179 \mathrm{mg} / \mathrm{l})$ was recorded in the month of April (summer) and minimum value $(70 \mathrm{mg} / \mathrm{l})$ in the month of October. Hujare [11] was reported total hardness was high during summer than monsoon and winter. High value of hardness during summer can be attributed to decrease in water volume and increase of rate of evaporation of water. Similar results were obtained in the present study.

\section{Chlorides-}

The values of chlorides range from $31.06 \mathrm{mg} / \mathrm{l}$ to $57.61 \mathrm{mg} / \mathrm{l}$. The maximum value $(57.61 \mathrm{mg} / \mathrm{l})$ was recorded in the month of May (summer) and minimum value $(31.06 \mathrm{mg} / \mathrm{l})$ in the month of February. In the present study maximum value of chloride reaches in summer. Similar results were reported by Swarnalatha and Narsing rao [12].

\section{Alkalinity -}

Total alkalinity ranges from $121.25 \mathrm{mg} / \mathrm{l}$ to $200 \mathrm{mg} / \mathrm{l}$. the maximum value $(200 \mathrm{mg} / \mathrm{l})$ was recorded in the month of May (summer) and minimum value $(121.25 \mathrm{mg} / \mathrm{l})$ in the month of January (winter). alkalinity was maximum value in April(summer) due to increase in bicarbonates in the water. Hujare [11] also reported similar results that it was maximum in summer and minimum in winter due to high photosynthetic rate.

\section{Phosphate -}

The value of phosphate fluctuates from $0.12 \mathrm{mg} / \mathrm{l}$ to $12.38 \mathrm{mg} / \mathrm{l}$. the maximum value $(12.38 \mathrm{mg} / \mathrm{l})$ was recorded in the month of August (monsoon) and minimum value in the month of October (winter). The high values of phosphate in August (monsoon) months are mainly due to rain, surface water runoff, agriculture run off; washer man activity could have also contributed to the inorganic phosphate content. Similar results reported by Arvindkumar [13].

\section{Nitrates -}

The values of nitrate ranges from $4.40 \mathrm{mg} / \mathrm{l}$ to $37.5 \mathrm{mg} / \mathrm{l}$. the maximum value $(37.5 \mathrm{mg} / \mathrm{l})$ was observed in the month of July (monsoon) and minimum $(4.40 \mathrm{mg} / \mathrm{l})$ in the month of November (winter).

\section{REFERENCES}

[1]. Pandey, A. K., Siddiqi S. Z. and Rama Rao (1993): Physico-chemical and biological characteristics of Husain sagar, an industrially polluted lake, Hyderabad. Proc. Acad. Environ. Biol. 2(2), 161-167.

[2]. Trivedy, R. K. and Goel P. K. (1986): Chemical and biological methods for water pollution studies, Environmental Publication, Karad, Maharashtra.

[3]. Kodarkar M. S. (1992): Methodology for water analysis, physico-chemical, Biological and Microbiological Indian Association of Aquatic Biologists Hyderbad; Pub.2: pp. 50.

[4]. APHA (1985): Standard Methods For Examination of Water and Wastewater, 20th Edition, American Public Health Association, Washington D. C.

[5]. Jayabhaye, U. M.; Pentewar M. S. And Hiware C. J. (2006): A Study on Physico-Chemical Parameters of a Minor Reservoir, Sawana, Hingoli District, Maharashtra.

[6]. Salve, V. B. and Hiware C. J. (2008): Study on water quality of Wanparakalpa reservoir Nagpur, Near Parli Vaijnath, District Beed. Marathwada region, J. Aqua. Biol., 21(2): 113-117. 
[7]. Khan, M. A. G and Choudhary S. H. (1994): Physical and chemical limnology of lake Kaptai, Bangladesh. Trop. Eco. 35(1): 35-51.

[8]. Kadam, M. S. Pampatwar D. V. and Mali R. P. (2007): Seasonal variations in different physicochemical characteristics in Masoli reservoir of Parbhani district, Maharashtra, J. Aqua. Biol. 22(1): 110-112.

[9]. Kamble, S. M.; Kamble A. H. and Narke S.Y.(2009): Study of physico-chemical parameters of Ruti dam, Tq. Ashti, dist. Beed, Maharashtra. J. Aqua. Biol. 24(2):86-89.

[10]. 10. Masood Ahmed and Krishnamurthy R.(1990): Hydrobiological studies of Wohar reservoir Aurangabad(Maharashtra state) India. J. Environ. Biol. 11(3), 335-343.

[11]. Hujare, M. S. (2008): Seasonal variation of physico-chemical parameters in the perennial tank of Talsande, Maharashtra. Ecotoxicol. Environ. Monit. 18(3): 233-242.

[12]. Swaranlatha, S. and A. Narsingrao. (1998): Ecological studies of Banjara lake with reference to water pollution. J. Envi. Biol. 19(2): 179-186.

[13]. Arvindkumar, (1995): Some Immunological Aspects of the Fresh water Tropical Wetland of Santhal. Pargana (Bihar) India, J. Envi. Poll.2 (3): 137-141. 